\title{
The Case Against Specialist Jurisdiction for Labour Law: The Philosophical Assumptions of a Common Law for Labour Relations
}

\author{
Nick Wailes*
}

The aim of this paper is to outline the philosophical assumptions that form the basis of the present call for the abolition of specialist jurisdiction for labour law in New Zealand. The discussion here focuses on Epstein's (1983a) "A common law for labour relations ...." because it is the key statement of the case against a specialist jurisdiction, and the conclusions he advances have played an important role in the debate about labour law in New Zealand. While academic literature has been largely critical of the call for the abolition of the Employment Court, there have been very few attempts to come to terms with the types of arguments used by the "abolitionists". It is argued that an adequate critique needs to be built on an understanding of the philosophical assumptions that are driving the current changes in labour relations legislation.

\section{Introduction}

Current debate about whether to retain or abolish the specialist jurisdiction for labour law has increasingly focused on the issue of whether the common law can adequately deal with the employment relationship in a general setting. While this line of argument has a long history, especially in the United Kingdom leading up to the Trade Disputes Act 1906 (Fox, 1985), the intrusion of a philosophically driven conception of what the common law ought to be has fundamentally recast the terms of reference for the debate in its contemporary form. The aim of this article is to provide a critique of the key example of the "abolitionist" argument, that stems from the redefinition of the common law - R.A. Epstein's (1983a) "A Common Law for Labour Relations ...." - by examining the behavioural assumptions that accompany such an argument. While it is generally acknowledged that Epstein's ideas have had a significant influence in shaping the "abolitionist" case (see for example Ryan and Walsh 1993, Anderson 1993, Brook 1990, 1991 ), there is no comprehensive or satisfactory attempt to provide an understanding of the nature of Epstein's argument. What follows is an attempt to fill this lacuna. It is divided into four sections. The first briefly reviews the debate about the status of the Employment Court. The second summarises Epstein's case for the use of common law principles and institutions to deal with employment relations, which form the basis of the present call for

* Lecturer, Department of Management Studies and Labour Relations, Tamaki Campus, The University of Auckland. The author would like to thank Nigel Haworth for his guidance in the writing of this article. I have also benefited from comments by John Deeks and Rose Ryan on an earlier draft of this paper. I would also like to thank the editor of the Journal and the anonymous referees for their suggestions. The remaining errors are mine alone. 
the abolition of the Employment Court. Section three demonstrates that the philosophical assumptions that Epstein brings to his analysis enable him to dismiss many of the criticisms that have been levelled at his analysis. Section four argues that an adequate critique of Epstein must be founded on an assessment of the philosophical assumptions that he brings to his work on labour relations - specifically, the theory of self interest and self ownership.

\section{The debate about the specialist jurisdiction}

In a series of recent articles Walsh and Ryan (Ryan and Walsh 1993, Walsh and Ryan 1993) have argued that the Employment Contracts Act (ECA) is theoretically inconsistent. In part, they locate this inconsistency in the nature of the policy process by which the ECA was finalised. Briefly, the formation of a new policy making community with strong links to employer groups, and like minded interest groups, fed into National's Manifesto aims for labour relations reform. While this reform agenda allowed the issues of bargaining and representation to be resolved in a fairly straight forward manner, the nature of the institutional structure to accompany these changes continued to be the focus of considerable debate. The result was a defeat of the institutional aspects of the "neo-conservative" reform agenda during the Options paper exercise. Ryan and Walsh (1993) attribute this to the way that Department of Labour officials retained control over the criteria against which the institutional options were to be judged. They argue that as a result of this policy making process, the institutional structures which are provided for in the ECA are more in line with the pluralistic philosophy of previous labour relations legislation than what they call the "neo-conservative contractual based theory" that underpins section I \& II of the Act ${ }^{1}$. On the basis of this assessment of the policy process, they suggest that the nature of the labour relations institutions is the last remaining unfinished business of the process of labour market deregulation that has taken place over the last decade.

Much of the recent concern with the status of the Employment Court is associated with the publication of the Business Roundtable and the Employers Federation's (Business Roundtable/Employers Federation, 1992) joint assessment of the decisions taken by the Court. For Ryan and Walsh, it signalled the beginning of a concerted campaign advocating the abolition of the Employment Court in favour of civil court jurisdiction. At the time, they argued that in the event of a National Government being re-elected in the 1992 general election, the abolition of the Employment Court would become a serious policy issue. However, the initial difficulties for National in securing a majority and more widely, the downgrading of "neo-conservative" policy options in the face of the erosion of electoral power, seems to have precluded institutional reform in the short term. In fact, it could be argued that the "pluralist" aspects of the ECA have been strengthened by the introduction of a minimum wage for under twenty year olds. Nevertheless, the Business Roundtable/ Employers Federation assessment of the Employment Court clearly signposts an agenda for

1 The division of the ECA in to a "neo- conservative" section (parts I \& II) and a pluralistic section (parts III \& IV) seems to have gained currency because of its neatness in analytical terms. However, this approach is misleading. In fact the emphasis on freedom of association rather than freedom of contract in part I of the Act represents a substantial moderation to Epstein's model which has not attracted any attention in the critical literature. The argument here is that the failure to come to terms with Epstein's argument allows these types of oversight. For a more rigorous assessment of the ECA as it measures up to Epstein's model see Brook 1991. 
reform which stems from the same theoretical model as the ECA itself. Thus, there is still a need to consider the Business Roundtable/Employers Federation assessment because of its implications for future policy reform.

Moreover, there are a number of important issues raised by the Business Roundtable/ Employers Federation document. The fact that the two organisations should publish a document together lends considerable support to the view that the Employers Federation has become increasingly radicalised over the last eight or nine years (Walsh, 1992; Roper, 1993). It also seems to reflect that the nature of the Employers Federation has been fundamentally altered by the ECA (Carroll \& Tremewan, 1993). No longer directly involved in the bargaining process, it has adopted a position closer to that of the Business Roundtable as a lobbying group.

More interestingly, in the context of the debate about the retention of the specialist jurisdiction, the Business Roundtable/Employers Federation assessment retains continuity with the position advocated by the Business Roundtable since at least the Green Paper process undertaken before the 1987 Labour Relations Act (Business Roundtable, 1986). This is summarised by Anderson (1993). He identifies the criticisms of the Employment Court with the long standing claims that specialised institutions pay too much attention to the content of contracts and have been prepared to read wide ranging implied terms into voluntary contracts. Anderson notes that the assumption of this argument is that the civil courts would produce judgments that were significantly different than those of the Employment Court. This reflects a philosophical belief in how the courts ought to function rather than the way they actually do function. His conclusion is that the transfer of jurisdiction to the civil courts would not result in a significant change in the nature of decisions because the civil courts have consistently upheld, and deferred to, the decisions of the Labour Court, the predecessor of the Employment Court. The implication is that the abolitionist case is one driven by theoretical assumptions derived from theorists like Epstein. On the basis of this assessment, it is important to examine the appropriateness of this philosophical model to labour relations legislation in New Zealand.

\section{Epstein's common law for labour relations}

The argument put forward by Epstein (1983a) stems from the application of his social and political philosophy to the issue of labour relations. These conclusions have typically been presented as the entire argument ${ }^{2}$. Epstein's broad conclusion is that common law principles provide the most appropriate basis on which to regulate employment relationships because they are based on a sound understanding of human nature. This section seeks to outline the conclusions that Epstein reaches, and that have been subsequently taken up in the policy debate about specialist jurisdiction. It attempts to relate these conclusions to the behavioural assumptions he brings to his analysis.

A good example is Brook (1990). Her case for the reform of labour legislation in New Zealand, including the abolition of a specialist jurisdiction, is heavily dependent on Epstein's argument for a minimal labour statute which gives predominance to common law principles. But it is clear that she is not aware of the philosophical inconsistencies this creates in her analysis. See Wailes (1993) for a more detailed discussion. 
Epstein defines the common law as the best set of private law principles that can be devised to handle the problems of labour relations. It is important to note that this definition differs significantly from the technical definition used by lawyers to denote the development of legal precedents from decisions of the courts not governed by statue. Epstein argues that given his alternative definition, the law of property and tort establish the framework of original rights in which voluntary transactions can take place. The benefit of such an approach, Epstein believes, is that it is capable of sustained application across a wide range of different specific cases. Added to this is the liberal principle that contracts are of mutual benefit to both parties in the transaction regardless of original entitlements. Such a libertarian framework, Epstein argues, is capable of dealing with all the issues that arise in any situation of voluntary transactions between individuals who are self interested.

$\mathrm{He}$ argues that the common law, so defined, creates legal entitlements among strangers without reference to personal status. He asserts that, apart from "unfortunate early flirtation with the law of criminal conspiracy", the common law proper took a very sound position in regulating employment relationships in the last quarter of the nineteenth century. It was in this period that the common law proper most closely approximated Epstein's model of how it ought to function because of the widespread application of contract law to employment matters. The strength of such an approach, Epstein asserts, is that it is based on the view that "every person owns his own person and can possess, use and dispose of his labour on whatever terms he sees fit" (1983a:1364). Further, this understanding of entitlements asserts that the right to disposition allows the specification of the correlative obligations that accompany the right to offer one's labour unhindered. Over time the original distribution of wealth is likely to change as labour is exchanged for leisure or for capital and, within this framework, no limitation is placed on the voluntary recombination of entitlements thus established.

Therefore, he argues that the decision to become an employer or an employee is strictly a private act, and cannot be the occasion for the increase of state regulation of private transactions. Rather, the role of the state is limited to ensuring the faithful enforcement of the voluntary agreements reached by individuals. Further, the identity of the parties to voluntary transactions should be of no special concern of the state. Therefore, if unions are formed voluntarily, without the use or threat of force, fraud or inducement to breach contract, they are easily integrated into the framework of a general theory of entitlements.

Epstein demonstrates the usefulness of this model by applying it to a number of specific cases related to labour relations. First, he argues that within this framework unions are not regarded as a criminal conspiracy and that the framework of tort law provides the boundary in which they can legitimately act in constraint of trade. For this reason, he argues that the closed shop can be accommodated within a common law framework provided that it is the outcome of a voluntary transaction. Secondly, he suggests that the same logic applies to the yellow dog contract because a voluntary agreement within the limits of that allowed by the common law must be accorded respect regardless of its content. The fact that wages are above zero and that differentials in wages exist between workers, for Epstein, is clear evidence that workers do not have unequal bargaining power or rather, that considerations of bargaining power are unimportant, because the contract is of mutual benefit to employers and employees. Further, he argues that those who support the banning of the yellow dog contract are confusing economic inequality with duress, which would imply that all bargains 
involved duress. Workers have the choice to retain their contract with their union and seek employment elsewhere. This conclusion is not moderated by utilitarian considerations because workers that accept yellow dog contracts will demand some compensation for giving up the gains of union membership. A third issue that Epstein addresses is that of picketing. He distinguishes two aspects of picketing - the threat to use force and the attempt to convey information. He argues that the threat to use force is covered by the law of assault, and while the attempt to convey information is legal, it is better to extend too much protection to the rights of others than too little in a situation where the two aspects are intertwined. Finally, he argues that there is no such thing as the right to strike because this involves the breach of contract. It is notable that the lockout, for Epstein, is analytically different from a strike, because the worker has the option to seek alternative employment, whereas an employer cannot easily take his/her production elsewhere.

On the basis of a sustained critique of the provisions of the United States' National Labour Relations (Wagner) Act, Epstein's main conclusion is that the common law, as he defines it, because of the simplicity of its procedures and principles, is well equipped to deal with the nature of labour relations. This is because the principles of his common law correspond to a situation in which the natural self interest of those involved is not mediated by other concerns. The extension of this argument is that there is no need for a specialist labour law of any type, other than a minimal code which merely states the common law principles that ought to guide approaches to employment relationships. Also it implies that there is no need for an institution that has expertise in labour matters because the theory of entitlements allows the unproblematic application of the general principles of property, tort and contract to labour matters, which are simply issues of property rights. For this reason, Epstein's approach is commonly called a general law approach.

In a later paper (1984a) Epstein argues for the return of the contract at will doctrine. $\mathrm{He}$ summarises the case against the contract at will as one which assumes that the structure of the labour market leaves employees vulnerable to coercion and exploitation in a situation where employers are arbitrarily able to end contracts. Given his view that the employment relationship is simply an issue of property rights, he rejects this assessment. While Epstein admits that contract at will is not ideal for every employment relationship, he argues that the parties should have the right to adopt this form of contract if they wish, and that this form should be implied in the absence of a specific agreement. For Epstein, the contract at will is important because it respects the freedom of individuals to negotiate on whatever terms they see fit. He also argues that the contract at will empowers both employers and employees to ensure that they obtain mutual benefit during the whole period of the employment relationship. He asserts that because either party has the power to end the contract at any time, the contract at will operates as a powerful constraint against the abuse of the relationship by one party or another. It is this argument, taken together with his entitlement theory, which points to what Epstein means by "a" common law for labour relations - it is a specific view of how the common law ought to function based on philosophical principles of human action. He is not referring to the common law as it is understood in its technical legal sense.

The recent "abolitionist" case in New Zealand has made substantial use of these ideas. The Business Roundtable has consistently maintained that the employment relationship should be dealt with according to contractual notions and that these are best addressed in the 
setting of the civil courts, under the auspices of a simplified common law based on the theory of individual entitlements. Furthermore, many of the features of Epstein's "common law for labour relations" can be identified in the provisions of the ECA with its emphasis on contractual arrangements between individual employers and employees. The Business Roundtable/Employers Federation (1992) assessment of the operation of the Employment Court is underpinned by a clear agenda for the abolition of the Employment Court in line with the philosophical conclusions of Epstein's model.

The importance of these ideas in New Zealand's contemporary labour relations raises the question what are the behavioural assumptions that drive Epstein's model? There are two aspects of Epstein's presentation of labour relations which relate to the way he understands human action. Firstly, he argues that in employment relationships humans act to maximise their self interest and the correspondence of common law, as he defines it, to this self interest makes it the best possible basis on which to regulate employment relationships. Secondly, he believes that the choice to become an employer or an employee is a strictly private one based on the individual preference for risk. Section four argues that these two claims are closely connected and stem from Epstein's philosophy of human action. A third claim that Epstein makes is that individuals own their labour and can use it as they see fit, within the limits of common law principles (which determine legality and capacity). Combined with the theory of self interest, Epstein believes that this notion of self ownership renders criticisms of his common law for labour relations meaningless.

\section{Epstein and the pluralist critique}

Epstein has been the subject of a number of criticisms from industrial lawyers in the United States. Broadly, these critiques have focused on two issues. Firstly, it is argued that Epstein presents the common law as if it was unchanging and that this is a major flaw in his argument. Getman and Kohler (1983) argue that this presentation masks the limited time period in which contract doctrine governed the employment relationship. They argue that the labour relations legislation that Epstein is so hostile to represents a reapplication of the traditional master and servant legal forms that dominated employment law before the intellectual experiment of using contract law. A second and related criticism is put forward by Verkuil (1983) who argues that Epstein misrepresents the way in which the common law has dealt with employment relationships in the period when the contract doctrine operated and, therefore, he fails to understand the reason that the employment relationship was taken away from the jurisdiction of the common law courts

However in a reply (1983b), Epstein dismisses these objections as misguided. He recognises the weakness of the pluralist position - it is essentially empirical and does not have a clear theoretical base. More importantly, in this context, he rejects the view that how the common law has functioned in the past is of any relevance to what he advocates. Epstein is not only interested in repealing the Wagner Act (and by extension specialist jurisdiction for labour law generally) but also in purifying the common law itself of intrusions that do not directly relate to the theory of entitlements outlined above. Therefore, the way in which the common law proper has dealt with the employment relationship prior to the development of contract is not his concern. Rather, he argues that those are the 
features of the common law which need to be done away with because they are not linked to the theory of self interest and self ownership. Epstein argues that one of the specific impurities in the common law is the view that there is a need for a separate body of law or separate institutions to deal with what are essentially matters of property relations, like employment.

The second criticism levelled at him - that he fails to take account of the historical circumstances under which the jurisdiction of labour law was taken away from the common law courts - is also wide of the mark. Epstein sees the actions of the courts in the period leading up to Wagner as demonstrating the need to reduce judicial activism and a reflection of the rapid pace of social change. It was not, he argues, a demonstration of any inherent failing of common law principles to deal with the employment relationship. Epstein's argument is that it is this mistaken assumption, underpinning all labour relations legislation, which is the source of the failure of these systems to promote efficient employment relationships. On this basis, Epstein is opposed to any notion of change or development in the common law itself. This can be seen in the way he defines the common law. $\mathrm{He}$ does not view it as a body of law based on precedent but the best (single) set of principles derived from the "libertarian and utilitarian traditions of Locke, Bentham and Mill" (1983b: 1435). Much of the confusion caused by Epstein's argument revolves around this point. In fact he is not talking about the common law proper, but rather a common law based on libertarian principles of human action.

Clearly, then, criticisms of the type put forward by Getman, Kohler and Verkuil do not correctly identify what Epstein believes to be the source of his case for a common law for labour relations. They do not acknowledge the link that Epstein makes between an understanding of human behaviour and the usefulness of common law principles. This is best understood in relation to the standard against which Epstein judges common law principles - individual freedom. "The protection of private contracts against government regulation is inseparably entwined with two elements - individual freedom . . . and the need to prevent legislative mis-behaviour" (Epstein 1984a:717). He sees the "importance of contract as an end in itself . . . (because it implies) the respect of individual liberty. It is unjust to abridge the economic liberties of an individual" (1984b:951). By not confronting this relationship, Getman, Kohler and Verkuil fail to understand the nature of Epstein's challenge to pluralism.

This same line of criticism has been taken up by those who wish to advocate the case for the retention of the Employment Court in New Zealand. Ryan and Walsh (1993) have explicitly referred to Getman and Kohler (1983) and Verkuil (1983) in putting their case forward for the retention of the specialist jurisdiction. They argue from these two pieces that, first, the criteria against which labour legislation should properly be judged relate to their workability. Second, they argue that Epstein's common law for labour relations assumes that the common law is unchanging. However, Epstein argues that the Wagner Act (and by extension a specialist jurisdiction in New Zealand) is not workable by any external standard (such as the one he advocates - individual liberty) and asserts that the economic decline of highly unionised sectors, in the US and elsewhere, is not simply a coincidence but rather a function of the way in which the legislation violates economic liberties. Epstein dismisses the type of challenge raised by Ryan and Walsh by arguing that their sources "offer no theory - normative or positive,.... it takes a theory to beat a theory" 
(1983b:1435). By itself the criterion of workability has no normative validity - unless they are prepared to establish a theoretical basis for pragmatism. Furthermore, in line with his view that contract law is closely related to human nature, Epstein (1980) does in fact argue that the common law should be static around the theory of entitlements, therefore rejecting the importance of accounts of how the common law has functioned. Epstein is not interested in how the common law has functioned but rather how it should function.

A second attempt to establish the basis for a specialist jurisdiction is put forward by Anderson (1993). He distinguishes two separate aspects of a defence of specialist jurisdiction. He acknowledges that a pragmatic view, advanced by Ryan and Walsh, which focuses simply on the factual nature of employment disputes cannot by itself provide the case for a specialist jurisdiction as opposed to a specialised division of the High Court. Therefore, the case for the retention of the Employment Court needs to be founded on the nature of employment law. He dismisses the view that since the passing of the ECA, employment law has been subsumed into the general law of contract because this leaves no sufficiently specialist field of labour law to allow the retention of a specialist jurisdiction.

Rather, he argues that employment law can be sufficiently differentiated from general law to justify specialist institutions. This view concentrates on the differences between legal forms and employment relations. He argues that common law is inherently individualistic and, as such, conflicts with the collective nature of industrial relations. Further, he believes that legal structures are adversarial and not well suited to reaching agreements between parties in an ongoing relationship. Therefore, Anderson suggests that employment relationship should be dealt with in an institutional setting which meets the following criteria of effectiveness - adequate provisions for proven violations of disputes of rights, relative speed, costs to the parties and the state, access by individual workers, and the perceptions of the parties directly involved. These criteria suggest the development of modes of legal reasoning rooted in the particular character of the employment relationship. Anderson argues that the contract form is an artificial legal construct which is not well suited to the nature of employment because it differs significantly from other commercial contracts. He, therefore, provides a theoretical basis for the workability thesis put forward by Ryan and Walsh.

This is an elegant argument but it does not by itself provide a basis on which to critique Epstein, and by extension the case put forward by the Business Roundtable and the Employers Federation for abolition of the specialist jurisdiction. Anderson does not adequately deal with the fact that Epstein's manifest assumption is that the employment relationship should be dealt with by contract law, and should indeed be treated as if it were any other commercial contract or property relation. Nor does he provide a satisfactory critique of Epstein's view that the employment relationship is best dealt with by a theory of entitlements because it equates most closely to human nature. Therefore, to be able to critique the present call for the abolition of the Employment Court, it is important to examine the nature of the behavioural assumptions underpinning Epstein's analysis. 


\section{Self interest and self ownership}

The implicit assumption of the Business Roundtable/Employers Federation assessment of the Employment Court is that the pluralist assumptions that have underpinned labour relations legislation, and form the basis for the criticisms discussed above, cannot be sustained in the face of Epstein's model. It is from this position that they suggest that the Employment Court's specialist jurisdiction is at odds, not only with the intention of the ECA, but also a sound understanding of how individuals behave. However, those who wish to draw these conclusions must accept Epstein's socio-biological and neo-liberal behavioural assumptions. This section argues that these behavioural assumptions are extremely problematic and any analysis based on them is seriously flawed.

How can Epstein claim that "the decision to become an employer or an employee is an entirely private one" (1983a:1366) based on individual preference for risk? It is this statement which disarms much of the pluralist critique because it denies the fundamental assumption that there is an imbalance of power in the employment relationship and that this is the source of conflict in the workplace. However, Epstein's claim is not an unproblematic notion. Rather it represents the summary of a complex set of behavioural assumptions which need to be examined further.

Epstein (1990) stresses that the most important features of human action, in most situations, are best understood by the theory of self-interest. He argues that the normative basis of social and political philosophy ought to be derived from this positive (descriptive) observation. Epstein's self interest thesis can be summarised as follows. In a wide variety of human activities, human action is best explained not by using social categories but rather by concentrating on biological factors. He argues that what is particular to humans, and therefore what constitutes their nature, is that they will maximise their self interest within certain moral, legal and social constraints. This he believes follows from the selection of the genotypes which maximise self interest as a means of survival. He moderates this "standard model of self interest" with a number of devices, such as inclusive fitness \& imperfect obligation ${ }^{3}$, but argues that in a situation of voluntary exchange between strangers, as in the employment relationship, a standard model of self interest most accurately predicts behaviour. On the basis of this formulation, Epstein attempts to assess the normative implications of self interest - distinguishing the constant and variable features of human nature in order to determine the social arrangements that hold the greatest long term social advantage. This "requires an understanding of the interaction between the self interest constant and diverse natural endowments" (1990:103). He argues that the persistence of self interest and variations in preferences is the strongest justification for the use of a decentralised system of property allocation, and therefore a common law regime based on these principles.

Using the biological derivation of self interest and the argument that (genetic) diversity produces differences in preferences and tastes for risk, he is able to argue that some

"Inclusive Fitness holds that all organisms act to maximise not only their individual fitness, but the fitness of their entire genetic line as well" (Epstein, 1990: 102 at footnote 2). This is a device that Epstein takes from social biology as a means of dealing with the difficulties that a simple egoistic assumption poses for his analysis. Imperfect obligation refers to religious belief, caring activity, etc. 
produces differences in preferences and tastes for risk, he is able to argue that some individuals assume the nature of employees and others of employers depending on their initial (biological) endowments. The fact that an employer has a higher taste for risk allows $\mathrm{him} / \mathrm{her}$ to have a greater say over the decisions in the business. Unlike Nozick (1974), Epstein acknowledges that voluntary exchanges generate negative externalities, but asserts that these are reduced as voluntary exchanges become routine for broad classes of transactions. Therefore, a common law for labour relations allows for predictability and reduces externalities from exchange. Further, he argues that a system based on private property and individual liberty will generate the closest approximation to the Pareto optimal social contract, given natural differences in preferences that cannot be measured.

There are a number of problems with Epstein's theory of self interest which raise doubts about its usefulness. Epstein's model stems from the application of socio-biology to his social and political philosophy. Rosenburg (1988) argues that for socio-biology to have any normative influence there are two key issues it has to address. First, it must show that the naturalistic fallacy ${ }^{4}$ can be overcome by demonstrating how a purely factual property of organisms can "underwrite their status as agents or loci of intrinsic value" (ibid:88). Secondly, if this can be achieved, it must show that this property is common, and peculiar to, all humans so that it will count as constituting our nature. This is exactly what Epstein tries to do. He deliberately ignores the critiques of Moore and Hume, and explicitly seeks to derive "ought" from "is". He uses the biological constant of self interest to satisfy the second condition. However, Rosenburg argues that models that use socio-biology cannot satisfy this condition because its underlying tenet is that there is no such property common and peculiar to each member of the species (Wilson, 1975), rather they require variation both within and between species. Therefore, it is not clear that the idea of a self interest residual is consistent with a socio-biological methodology.

In the absence of being able to establish any direct normative importance, Rosenburg argues that the most that can be expected from these types of models is to tell a plausible story, but questions the value of such an exercise. In effect Epstein's model confronts the genetic fallacy - to infer that a particular normative conclusion is right or well grounded from a purely causal account of its origins. Epstein's model of self interest, therefore, is severely limited in its ability to underpin normative conclusions. Given the role biological foundations play in Epstein's work on labour relations, it is important to provide an alternative evaluation of self interest.

Lewontin et al. (1982) argue that models like the one being considered here reflect the need for bourgeois society to explain continued inequalities that exist in capitalism. Epstein's work on labour relations seeks to justify, or dismiss as unimportant, the inequalities that exist in employment relations. They argue that "the ideology of equality has become a weapon for, rather than a weapon against, a society of inequality by relocating the cause of the inequality from the structure of society to the nature of individuals" (1982:5). It is possible to situate this project in Epstein's work. He expresses the inequalities that exist between individuals in terms of the process of natural selection, but at the same time argues

4

The naturalistic fallacy was first identified by G. Moore in 1903 and applies to "any inference that purports to derive a normative conclusion from purely factual premises" (Bullock et al., 1988). 
the common law principle of not considering the positions of the parties to a contract, independent of the functioning of that contract.

Epstein's self interest thesis conforms to the three features of a biologically deterministic argument. He locates inequality in the genetic inheritance of the individual. Thus he attributes an intrinsic merit and ability to those who are better off, in this case employers. Secondly, because merit and ability are coded for in an individual's genes they are passed from generation to generation. Lewontin et al. argue that this construction confuses the two meanings of inheritance - monetary and genetic, legitimising the passage of social power from generation to generation. Thirdly, Epstein uses the presence of genetic differences to explain the development of hierarchical structures as natural. In doing so, Epstein falsely equates innate with unchanging and wrongly assumes that he can overcome the naturalistic fallacy.

The second behavioural assumption that Epstein relies on is that of self ownership. The key to his argument that the common law, as he defines it, can effectively deal with the employment relationship is his ability to assume that everybody owns their own labour, and can dispose of it as they see fit. In other words he seeks to reduce employment to a matter of exchanges of property rights. This view runs counter to the pluralist position that labour is not simply a factor of production. Brook (1990), who relies heavily on Epstein, argues that to say that labour is a commodity is simply to say that it has value. This model can be characterised as one which is structured around a Lockean "person". Epstein, in relying on self ownership, places the ideal-typical "person" developed by Locke at the heart of his argument. Levine (1988) argues that the profound changes associated with the development of capitalism in the seventeenth century required the development of ideal-typical types to act as both a spur to adoption of capitalism and to justify the inequalities that capitalism produced. MacPherson (1962) argues that Locke's great achievement was to justify continued inequality in the face of a formal equality, and that the means by which he did this was in arguing that each individual owned his or her own labour. This is because self ownership is not inconsistent with the right to alienate one's labour in return for a wage, thus justifying unequal property as a natural feature that exists prior to the formation of civil society. Because, to partake in capitalism, individuals had to have initial endowments, Locke's ideal typical type assigned (differential) initial endowments to the (pre-social) state of nature. Epstein uses socio-biology to construct these pre-social differences. Levine argues that this formulation is inherently pro-capitalist and excludes any notion of inequality from the analysis, because inequities are seen as a function of nature and not society. Therefore, Epstein's use of self ownership allows him to claim that there is no inequality in the employment relationship.

Furthermore, even given the general problems associated with using a Lockean person, there are a number of specific problems with the way Epstein uses and constructs this ideal typical type that undermine his behavioural assumptions. These will be dealt with briefly here. The first problem with Epstein's use of the Lockean person is that he employs this device on the basis of weak informational constraints about the slope of preferences, rather than on the basis of moral apriorism, as Nozick (1974) does. This creates significant confusion in his argument. Epstein excludes the state from having a useful role in (inter alia) regulating the employment relationship because it lacks the necessary information about the slope of preferences of individuals, but does not exclude this possibility in theory. 
about the slope of preferences of individuals, but does not exclude this possibility in theory. Therefore, his reversion to a Lockean formation is a secondary device. However, his analysis then proceeds from a position which assumes the existence of the individual prior to the social - thus assuming that the Lockean person is primary.

A second, and related problem, is Epstein's reconstruction of the status of appropriation in the Lockean framework. Locke argued that individuals had the right to the product of their labour as long as there was as much and as good left for others. However, as Epstein notes (1984c) in a world of scarcity, this condition is impossible to satisfy. He, therefore, uses a welfare constraint - normally known as a Lockean proviso. The appropriation of internal resources, generated through self interest, does not affect the welfare of others because they are not accessible to others. However, external appropriation is more problematic, because as he has already acknowledged scarcity prevents satisfaction of the sufficiency principle. $\mathrm{He}$ attempts to overcome this by arguing that the extension of voluntary transactions limits the welfare losses associated with external appropriation. However, it is not at all clear that self ownership necessarily implies justifiable control over external resources, except where it is already assumed that a capitalist market exists and that this is just. Cohen (1985 \& 1986) demonstrates that even where individuals are self owning, joint control of external resources can result in a just distribution. This is contrary to Epstein's implicit assumption that self ownership necessitates a hierarchical social structure. Broadly, the status of self ownership in Epstein's model is uncertain and confused, and the logical consistency that he claims for his analysis of labour relations relies on badly constructed behavioural assumptions.

\section{Conclusion: a common law for labour relations?}

The conclusions that follow from this discussion pose some serious questions regarding the usefulness of Epstein's "common law for labour relations" as the theoretical underpinning for changes in labour legislation in New Zealand. Epstein's case for the abolition of a specialist jurisdiction and the application of common law principles, as he defines them, to the employment relationship rest on a set of radical behavioural assumptions. This article has demonstrated a number of key features about Epstein's argument. It has shown that Epstein's case for the abolition of the specialist jurisdiction rests upon the thesis of self interest and self ownership. It has been shown that these behavioural assumptions cannot be sustained. Specifically, the theory of self interest confronts the naturalistic fallacy. Without normative status, it simply operates in a deterministic fashion to exclude inequality from Epstein's analysis. Also, the use of the Lockean person is confused both in its status and its construction. The implication of this critique is that abolition of the Employment Court, and the application of the common law principles that Epstein advocates to employment relations, are likely to have adverse effects on employees because they lack initial endowments.

However, as has been noted, Epstein's model represents not only a call for the abolition of the specialist jurisdiction, but also a complete redefinition of the common law itself. Thus it can be expected that a transferral of jurisdiction to the High Court would not significantly alter the nature of the decisions that the Business Roundtable and Employers Federation 
generally, the logic of the argument against a specialist jurisdiction for labour law is not separate or different to the logic underpinning the Employment Contracts Act as a whole. This suggests that the behavioural assumptions that underpin the ECA are derived from a radical model of entitlements not capable of dealing with employment relationships. The extent to which the ECA deviates from the model put forward by Epstein means that there is still space for further radical reform of labour relations in New Zealand. Currently, the view is that the avenue of reform is limited only to the institutional structure of the ECA. This view may need to be modified.

Finally, those who wish to advocate the retention of a specialist jurisdiction for labour law need to go back to first principles by outlining the behavioural assumptions that underpin a pluralist model of labour relationships. Attempts by Ryan and Walsh and by Anderson point the way for such a re-examination. However, this cannot be done in isolation from a critique of the Employment Contracts Act as a whole.

\section{References}

Anderson, G. (1993), Specialist Employment Law and Specialist Institutions, Paper presented to NZIRR seminar, 23rd April, Wellington.

Brook, P. (1989), Reform the Labour Market. In Walker, S. (ed) Rogernomics: Reshaping New Zealand's Economy, Auckland, New Zealand Centre for Independent Studies.

Brook, P. (1990), Freedom at Work: The Case for Reforming Labour Law in New Zealand, Auckland, Oxford University Press.

Brook, P. (1991), New Zealand's Employment Contracts Act: An Incomplete Revolution, Policy 7: 12-14.

Bullock, A., Stallybrass, O. and Trombley, S. (eds, 1988), The Fontana Dictionary of Modern Thought, 2nd edition, London, Fontana Press.

Carroll, P. and Tremewan, P. (1993), Organising Employers: the Effects of the Act on the Auckland Employers Federation. In Harbridge, R. (ed), Employment Contracts: New Zealand Experiences, Wellington, Victoria University Press.

Cohen, G.A. (1985), Nozick on Appropriation, New Left Review, 150: 89-107.

Cohen, G.A. (1986), Self Ownership, World Ownership and Equality: Part II, Social Philosophy and Policy, 3(2): 77-96.

Epstein, R.A. (1980), The Static Conception of the Common Law, in The Journal of Legal Studies, 9: 253-275.

Epstein, R.A. (1983a), A Common Law for Labor Relations: A Critique of the New Deal Labor Legislation, The Yale Law Journal, 92(8): 1357-1408. 
Epstein, R.A. (1983b), A Common Law for Labor Relations and Reality: A Rejoinder to Professors Getman and Kohler, The Yale Law Journal, 92(8): 1435-1441.

Epstein, R.A. (1984a), Toward a Revitalization of the Contracts Clause, University of Chicago Law Review, 51(3): 703-751.

Epstein, R.A. (1984b), In Defence of Contract at Will, University of Chicago Law Review, 51(4): $947-982$.

Epstein, R.A. (1984c), Takings: Private Property and the Power of the Eminent Domain, Harvard, Harvard University Press.

Epstein, R.A. (1990), The Varieties of Self Interest, Social Philosophy and Policy, 8(1): 102-120.

Fox, A. (1985), History and Heritage: The Social Origins of the British Industrial Relations System, London, Allen \& Unwin.

Getman, J.G. \& Kohler, T.C. (1983), The Common Law, Labour Law and Reality: A Response to Professor Epstein, The Yale Law Review, 92(8): 1415-1434.

Levine, A. (1988), Capitalist Persons, Social Philosophy and Policy, 6(1): 39-59.

Lewontin, R., Rose, S. and Kamin, L. (1982), Bourgeois Ideology and the Origins of Biological Determinism, Race and Class, 23(1): 1-16.

MacPherson, C.B. (1962), The Political Theory of Possessive Individualism: From Hobbes to Locke, Oxford, Oxford University Press.

New Zealand Business Roundtable (1986), New Zealand Labour Market Reform: A Submission in Response to the Green Paper, Wellington, New Zealand Business Roundtable.

New Zealand Business Roundtable and New Zealand Employers Federation (1992), The Labour/Employment Court: An Analysis of the Labour/Employment's Court Approach to the Interpretation and Application of Employment Legislation, Wellington, New Zealand Business Roundtable and New Zealand Employers Federation.

Nozick, R. (1974), Anarchy, State and Utopia, Oxford, Basil Blackwell.

Roper, B. (1993), A Level Playing Field? Business Political Activism and State Policy Formulation, in Roper, B. \& Rudd, C. (eds) State and Economy in New Zealand, Auckland, Oxford University Press. 
Ryan, R. and Walsh, P. (1993), Common Law versus Labour Law: the New Zealand Debate. In Haworth, N, Hill, M. and Wailes, N. (eds), Divergent Paths? Industrial Relations in Australia, New Zealand and the Asia-Pacific Region, Proceedings of the 7th AIRAANZ Conference, Auckland, Association of Industrial Relations Academics of Australia and New Zealand.

Rosenburg, A. (1990), The Biological Justification of Ethics: A Best Case Scenario, Social Philosophy and Policy, 8(1): 86-101.

Tomlins, C. (1985), The State and the Union: Labour Relations, the Law and Organised Labour in America, 1880-1960, Cambridge, Cambridge University Press.

Verkuil, P. (1983), Whose Common Law for Labour Relations? Comment on Epstein, The Yale Law Review, 92(8): 1409-1414.

Wailes, N. (1993), Taking Liberty with Freedom: Towards a Critique of Freedom at Work, MPhil Thesis, University of Auckland.

Walsh, P. (1992), The Employment Contracts Act. In Boston, J. \& Dalziel, P. (eds.), The Decent Society? Essays in Response to National's Social and Economic Policy, Auckland, Oxford University Press.

Walsh, P. \& Ryan R. (1993), The Making of the Employment Contracts Act. In Harbridge, R. (ed.), Employment Contracts: New Zealand Experiences, Wellington, Victoria University Press.

Wilson, E.O. (1975), Sociobiology: The New Synthesis, Massachusetts, Cambridge University Press. 


\section{Relations industrielles Industrial Relations}

Revue trimestrielle bilingue publiée depuis 1945 par le Département des relations industrielles de I'Université Laval. Relations industrielles/Industrial Relations est la seule publication scientifique du genre au Canada et la plus vieille au monde.

A forte saveur internationale, Relations industrielles/Industrial Relations s'est acquise une solide réputation tant au Canada qu'à l'étranger. Elle est reconnue officiellement par l'Association canadienne des relations industrielles.

Les articles portent sur tous les aspects des relations industrielles entendues dans un sens large. Ceux-ci sont publiés dans la langue de l'auteur, soit l'anglais, soit le français et sont accompagnés d'un résumé dans l'autre langue. Ils sont catalogués dans plusieurs index analytiques. Chaque numéro comprend en outre des recensions, des chroniques régulières et des bibliographies abondantes. Chaque article proposé est soumis à deux évaluateurs anonymes.

Relations industrielles/Industrial Relations s'adresse tant aux praticiens et praticiennes dans le domaine qu'aux universitaires. Ses abonnés sont répartis dans plus de trente pays à travers le monde.

Individus/Individuals

Institutions

Département des relations industrielles

Cité universitaire, Québec, Qc

Canada $\mathrm{C}_{1} \mathrm{~K} 7 \mathrm{P}_{4}$
A bilingual quarterly published since 1945 by the Department of Industrial Relations, Université Laval, Relations industrielles/Industrial Relations was the first academic journal of industrial relations in the world and is the only one in $\mathrm{Ca}$ nada.

With its international flavour, Relations industrielles/Industrial Relations has an excellent-reputation in Canada and abroad. It is officialy recognized by the Canadian Industrial Relations Association.

Articles focus on all aspects of the world of work. They appear in either French or English with a full summary in the other language. Each issue includes book reviews. regular features and a bibliography. All manuscripts are reviewed by at least two anonymous referees.

Relations industrielles/Industrial Relations is of prime importance for academics, students, human resources and labour relations managers, policy makers and observers. The Journal is distributed in more than thirty countries around the world.

\section{Abonnement annuel/Annual subscription}

Québec

Autres provinces/Other provinces

Autres pays/Other countries

Québec

Autres provinces/Other provinces

Autres pays/Other countries

Téléphone

Télécopieur/FAX (418) 656-3175
$27,73 \$$ CAN

$25,68 \$$ CAN

$24,00 \$$ US

$55,47 \$ \mathrm{CAN}$

$51,36 \$$ CAN

$48,00 \$$ US

Canada CIK 7P4 